\title{
FACTORS AFFECTING FINANCIAL LITERACY RATE
MILLENNIAL IN MALAYSIA
}

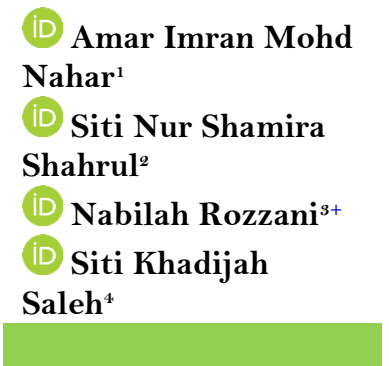

${ }^{1,2, s, 4}$ Faculty of Business Management and Professional Studies, Management and Science University, Malaysia.

'Email: amarimran.nahar@gmail.com

${ }^{2}$ Email:shamirashahrul@gmail.com

${ }^{s}$ Email:nabilah.rozzani@gmail.com

${ }^{4}$ Email: sitikhadijah@msu.edu.my

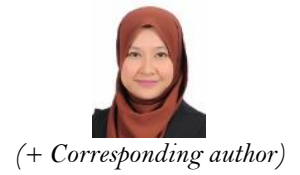

(+ Corresponding author)

\section{Article History}

Received: 6 January 2022 Revised: 9 February 2022 Accepted: 23 February 2022 Published: 2 March 2022

\section{Keywords}

Financial literacy Millennial

Financial education Financial knowledge

Financial behavior

Financial planning

Malaysia.

\begin{abstract}
Without being informed of financial management skills, many people are struggling financially as they are unaware of how to plan and manage money to make wise decisions regarding their finances. They are usually careless with spending money and do not plan effectively for their future. Most times, they would rely on cash in hand rather than doing effective planning to save or invest. Improper and inadequate planning can be a result of lacking financial knowledge and low literacy. This study investigates several factors of education, income, marital status, upbringing and influence, as well as its impacts toward financial literacy rate among millennials in Malaysia. This study employs quantitative research with primary data gathered using questionnaire from millennials residing in Malaysia. Results and findings of this study indicates that there is positive and significant relationship between education level and level of income with financial literacy rate of millennials in Malaysia.
\end{abstract}

Contribution/ Originality: This study investigates factors such as usage of internet and upbringing which are closely linked to millennial and whether it affects one's financial literacy or not. Results of this research are hoped to contribute to policymakers and financial institutions who are keen to boost the financial literacy of Malaysian millennial.

\section{INTRODUCTION}

Financial literacy is a set of skills that comprises of credit management, debt management and financial management. This set of skills also include knowledge, which enables individuals to choose and make effective decisions towards their financial well-being. This set of skills has been proven by many researchers to be very important and needed for individuals to fully utilize and survive with comfort in this era. This is because millennials nowadays are less keen to understand how money works, for which subsequently they do not have basic financial knowledge to go around and make wise decision financially (Xu \& Zia, 2012). Due this phenomenon, many countries especially Malaysia in this rapid developing era are still lacking in various aspects of financial literacy, for which their citizen fail to really understand the importance of financial literacy. Many are still stuck with the most basic financial knowledge and many others are not financially educated for them to be able to manage financial risk and avoid any problems that can occur due to the lack of financial literacy. 
Without being informed or having this set of skills, many people are struggling financially as they are unaware of how to plan or how to manage and make wise decisions regarding financial choices like investing, savings and borrowing. They are usually careless with spending money and do not plan effectively for their future. Most of the time, they would rely on their money that are available only in hand rather than doing effective planning to save or invest. Improper and inadequate planning can be a result of lacking financial knowledge and low literacy. Research done by Gale and Levine (2010) mentioned that those who are financially literate are usually more able to plan accordingly to their future financial needs and manage their money inflow and outflow decently. They would also become more aware of the risks, dangers and problems that can financially affect them in the future.

Research done by Asian Institute of Finance (AIF) in 2015 showed that 58 per cent of millennials are deemed to have average financial knowledge; while 28 per cent felt confident in their financial literacy and ability to handle financial matters. Majority of millennials are living on the edge with high-cost borrowing, with 38 per cent taking out personal loan and 47 per cent being engaged with high credit card bills. Only 37 per cent were able to seek professional advice regarding financial issues. Meanwhile, 40 per cent would spend more than they can afford and 70 per cent were unable to live comfortably within their current income. As such, only 42 per cent of the respondents has taken part in retirement and future planning.

Based on the findings from the AIF research, it becomes clear that many millennials are having issues financially, where one of the causes come from poor financial literacy. Hence, the problem statement for this study was formulated based on the issue millennials face financially and how factors impacting millennials financial literacy can be determined. The issues surrounding the study focuses on how millennials are struggling in their financial wellbeing with many unable to fully sustain their daily lives and live comfortably due to financial constraints that might stem from them being financially illiterate.

Since financial literacy is quite a popular topic worldwide, there are many research papers and researchers that are experienced in conducting this type of research to find relevant answers. Research done all over the world has proven that those with low financial literacy rate will have an issue with financial planning and this results to insufficient savings for the future and retirement (Lusardi \& Mitchell, 2011, 2014) There are many knowledges we can gain by reading these papers as it has been researched and documented in a detailed manner with relevant information. Thus, we can say there some things already known about the problem as stated by The Credit Counselling and Debt Management Agency, or commonly known as Agensi Kaunseling dan Pengurusan Kredit (AKPK) in 2015, financial literacy rate in Malaysia is on the low side when compared to other countries. AKPK has also released that 13.80 per cent of their participants for their debt management program are millennials which poses a concern as young people are struggling with debt.

Moreover, we can also find information like millennials are generally struggling with their financial and are unable to sustain their income for the future effectively. It is also a known fact that many people of the public are not taking financial knowledge and financial literacy as something serious and important and feel like it is okay to not know basic financial literacy as they feel like they do not need to use the knowledge when it is very important in many situations, as stated by the Ringgitplus in 2018.

Realizing this issue among many of the younger generation in Malaysia, the objectives of this paper are hence to investigate the significance of education level, level of income, marital status, upbringing, and external influence towards financial literacy rate of millennials in Malaysia. Thus, this study was conducted to investigate the factors surrounding financial literacy rate of millennials in Malaysia. The factors will help bring light to underlying issues and causes of why many are struggling with financial literacy and how certain factors help increase an individual's financial literacy rate. As part of this paper, some recommendations and suggestions that are relevant to the research are provided on how financial literacy can be increased. This paper is structured as follows: First section consists of introduction to the topic with relevant research question. The second section follows a literature review 
with formulation of hypothesis along with conceptual framework. As for the third section, it highlights the methodology. Section four discusses the tests and findings of study with the last section concluding the study.

\section{LITERATURE REVIEW}

Past researchers like Hwee, Lin, and Sellapan (2010) also Eisner (2005) has stated that millennials are increasing in the workforce population, and many were born during the economy boom, hence benefitted the opportunities and have a better quality of life. They agreed on millennials being more indecisive in their lifestyle which includes their financial wellbeing. Findings have found that millennials have higher credit problems despite living in a better economy than other age cohorts. Many lack the awareness of savings and retirement planning which led to the overwhelming financial distress. According to Huston (2010) financial literacy is one of the important elements in human capital which aid in increasement of expected lifetime utility of financial activities consumption, which will strengthen financial wellbeing of an individual.

A study by Atkinson and Messy (2012) has indicated that poor financial literacy is present all over the globe with Malaysia listed as having low financial literacy rate. The low financial literacy is prevalent all over the world as many lack financial knowledge and financial wellbeing despite living in developed countries. Hence, showing that lack of financial literacy is a global problem, and both developed and undeveloped countries suffer from financial illiteracy. Financial illiteracy has caused many to be less prepares during retirement (Lusardi \& Mitchell, 2007).

A research paper done on financial literacy and personal financial planning in Klang Valley, Malaysia by Boon, Yee, and Ting (2011) suggested that most individuals who have not implemented personal financial planning due to lack of their financial literacy level and many are still hesitant to seek professional help. Another research on the level of financial literacy in Malaysia by Kimiyaghalam and Yap (2017) showed that near to half of Malaysians in this survey have some basic financial knowledge, but in terms advance financial concepts such as the function of bond and stock and diversification, many are still lacking on the knowledge of what those functions really do.

Further, Tie and Nizam (2016) had argued that numerous efforts and initiatives should be taken to increase financial literacy of Gen-Y in Malaysia. This research had also highlighted on how Gen-Y are dealing with financial affairs and financial well-being. A positive correlation can be seen between financial satisfaction with these two variables that make up financial literacy and extant literature. Yew, Yong, Cheong, and Tey (2017) discussed on students' financial knowledge, reasons for the lack of knowledge, their attitudes toward financial management and their spending behaviour. The results have shown that college and university students in Malaysia have low financial literacy.

From past research papers and many sources, it has been found that financial literacy rate of Malaysia is on the lower side when compared to other countries. Many are still not aware regarding the importance of financial education and financial knowledge. Financial literacy is very important as we are constantly dealing with money. Having good financial literacy will help us in achieving a better life and comfortable future. Financial literacy plays a big role in one's financial satisfaction. There are many different factors that affect financial literacy rate of millennials.

\subsection{Education Level}

Level of education may play an important role in determining the level of financial literacy. Education is generally linked with better knowledge in handling things especially if you are well thought and informed. Past researchers such as Kimiyaghalam and Yap (2017) have found that those who receive higher education levels are more financial educated and are able to overcome financial distress. Someone who is educated at a master's level will have a higher financial literacy rate as opposed to those who are in the diploma level. This is due to the syllabus of a higher education being more detailed and more informative. Those of a higher education level might also have more experience than those of a lower one thus this affects the financial literacy rate of an individual. 
Those who are more educated in financial background has a higher financial literacy rate than those who do not according to research done by Beck and Garris (2019). Someone who is educated in the financial field will learn more on financial planning, investing, diversification and financial well-being compared to someone who is educated in a different field. Thus, we can say that the higher the level of education, the more well informed the person will be in managing their financials. Education is very important because it helps us understand and implement knowledge into our daily lives. Schools that teach and expose economic subjects to students will increase the student's financial literacy level in the future (Lusardi \& Mitchell, 2007). Studying economics in high school or at a higher level will help individuals to have a higher financial literacy level. Thus, the first hypothesis for the current study is formulated as follows:

H1: There is a positive and significant relationship between education level and financial literacy rate of millennials in Malaysia.

\subsection{Level of Income}

Income is a source of money, and this is the commodity that is being used to get through individual's daily lives for example buying food, shop for necessities and putting a roof above our heads. Without proper income, we will be struggling to make end meets and this may result in severe financial distress that affects your physical and mental health. Many have resort to borrowing and loans if their income is not enough which may benefit but at the same time pose a risk towards their financial well-being.

Research done by Murugiah (2016) found that those who earn a lower income or minimum wage are more associated with poor level of financial literacy. This however contradicts with research done by Diener, Sandvik, Seidlitz, and Diener (1993) who found opposite result. Those with a lower income tend to use up their money because it is just enough for them to get by, thus, it is hard for them to save up and invest their money. Lower income individuals are at times associated with having lower education levels, meaning they also receive less financial education and knowledge regarding handling money.

Those with a higher income are more prone to be more financially literate than those earning low wages. This was proven by Kimiyaghalam and Yap (2017), where their research found that higher income individuals are more prone to be inside the highest bracket of financial literacy level in both basic and advanced levels. The research also stated that those who are receiving middle income are average in financial literacy and this supports that the higher income you receive the higher financial literacy you have. Thus, the second hypothesis for the current study is formulated as follows:

H2: There is a positive and significant relationship between level of income and financial literacy rate of millennials in Malaysia.

\subsection{Marital Status}

Some researchers have noted that those who are married are more financially literate although another researcher has found that the marital status does not matter and the result came to be almost the same and there is no significant gap at all (Marzieh, Hosein, Mehrizi, \& Roshan, 2013; Murugiah, 2016). The result is quite inconclusive as different researchers have different results.

As stated by Calamato (2010) those who have a lower financial literacy level may endanger the well-being of their relationship by making poor decisions regarding their financial situation and thus may result in debts in the long term. Married people may have their own family and does having a larger number of responsibilities will make people be more prone to have financial education and awareness regarding financial well-being as opposed to those who live a single life (Grigion, Vieira, \& Kirch, 2015). Logically, by having more responsibilities, an individual would have to be equipped this adequate financial knowledge as he or she will be spending money on raising family and learn on how to manage personal income. 
However, some researchers found negative correlation regarding number of responsibilities with financial literacy level. Research done by Servon and Kaestner (2008) found that individuals with two or three children have almost the same financial literacy level as those with one child or lesser. Moreover, families with more dependants are more likely to have a lower financial literacy level than those with less dependants (Mottola, 2013). It might seem baffling as one would assume that those with more responsibilities will strive to be more financially literate and ensure the financial well-being of their family, but the opposite case has been observed by past researchers. Thus, the third hypothesis for the current study is formulated as follows:

H3: There is a positive and significant relationship between marital status and financial literacy rate of millennials in Malaysia.

\subsection{Upbringing}

Parents might play a part in affecting their children financial literacy. Some studies have supported this theory where results show that many individuals learn financial management first-hand from their parents (Clarke, Heaton, Israelsen, \& Eggett, 2005; Pinto, Parente, \& Mansfield, 2005). Many have reported that they learned money management with their parents since young. Research done by Jorgensen (2007) has shown that children are influenced by parent's financial behaviour. Meanwhile, Mandell (2008) stated that parent's education level is related with financial literacy of individuals. This further supports that parental education and upbringing play a major role in their children's financial literacy level.

Parents play an important role in ensuring that their children receive the right and correct financial education since young so that they can financially prosper and understand how to financially plan their lives. Parents who teach their children the basics of financial education will affect the financial literacy rate as the children themselves will be more aware regarding the importance of financial education at a young age.

Having financial education at a young age will help in increasing the financial literacy and are able to make wise financial decisions in their latter life. Children tend to learn a lot during their early years; thus, it is important for parents to ensure that their children receive adequate financial education so they can be more involved and understand better at a younger age. Thus, the fourth hypothesis for the current study is formulated as follows:

H4: There is a positive and significant relationship between upbringing and financial literacy rate of millennials in Malaysia.

\subsection{Influence}

Influence is among the less tested factors in regards towards financial literacy. Internet is widely used by many generations in this current era as it is a platform where everything is at your fingertips. As internet is a fastgrowing platform where you can access many different information, we believe there is a correlation between the influence of internet and financial literacy. 33 per cent of students use media as means of accessing financial knowledge (Lyons, Palmer, Jayaratne, \& Scherpf, 2006). Other researchers such as Ismail, Serguieva, and Singh (2011) found that media like television, newspaper and social media does influence individuals to save and increase their financial literacy. As information is widely available and usage of media is increasing day by day, it will have an impact towards an individual's financial literacy. Many media nowadays are used to promote and spread awareness regarding the importance of financial literacy. Thus, influence has an impact towards financial literacy rate of an individual as they are directly involved with their personal lives. Internet may become a bigger role in the future as we will start to progress more digitally and rely on the internet to help us with financial literacy and education. Thus, the last hypothesis for the current study is formulated as follows:

H5: There is a positive and significant relationship between influence and financial literacy rate of millennials in Malaysia.

The research framework employed in the current study is depicted in Figure 1. 


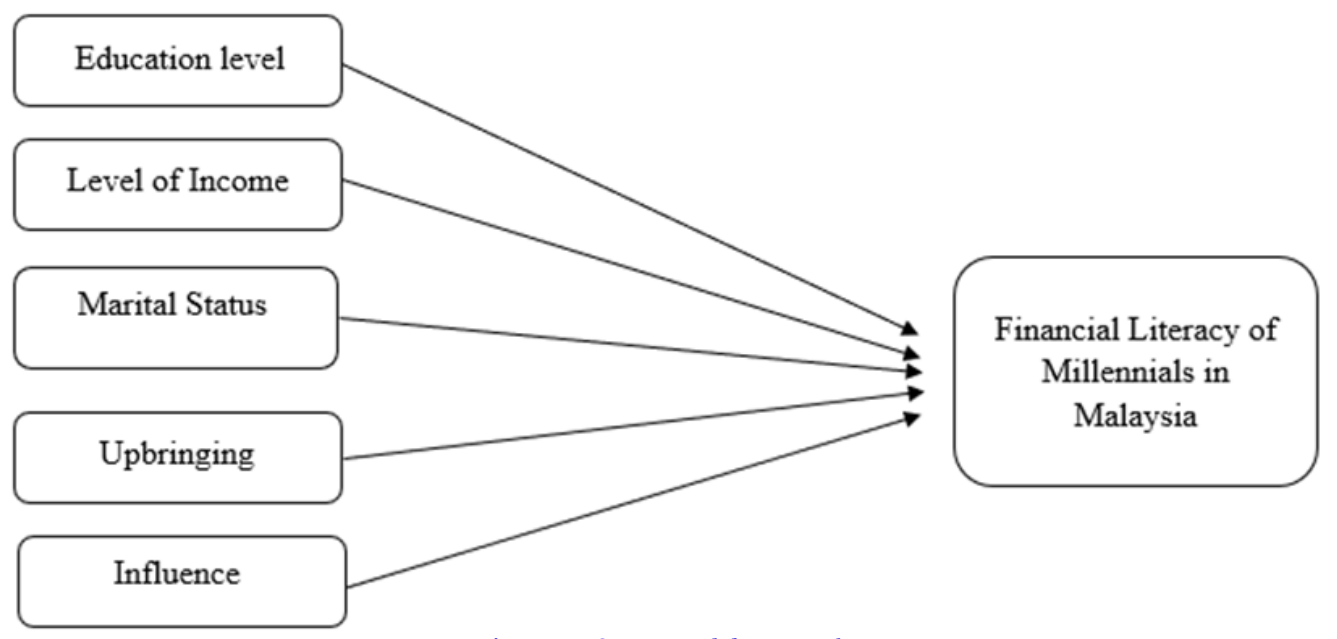

Figure 1. Conceptual framework.

\section{METHODOLOGY}

This study is categorized as a quantitative study as its research design. The data collected for this study is a primary data with first-hand respondents. Several variables are selected to be investigated which are level of education, level of income, marital status, upbringing, and influence. The current study had focused on determining the financial literacy rate of millennials along with the factors affecting it and what are the initiatives to help increase financial literacy. This study is a deductive study as construction of framework is done by examining existing variables by other researchers beforehand. Several variables are adopted to our research and tackles a different perspective of factors affecting financial literacy of millennials in Malaysia. Formulation of hypotheses are also done beforehand with the selected variables which indicates the relationship of level of education, level of income, marital status, upbringing, and influence with financial literacy. Several tests and methods are used to investigate the significance of variables selected. A pilot study has been conducted as to see whether the study was feasible and reliable.

The target population is millennials living in Malaysia and the sample of this study is 109 millennials across Malaysia. The sample mainly comes from Selangor as a lot of millennials are concentrated in this area and many of the respondents are living in Selangor. A random sampling has been utilized for the data collection of this study as to ensure that the data collected will not be biased. The sampling method is random as the questionnaire used for this study is spread through social media, hence respondents are randomly selected from different parts of Malaysia.

The data for the study was obtained through an online questionnaire via Google Forms. The questions include on financial literacy topics such as savings and spending, financial planning, as well as investment. Respondents are to answer the questions based on a 5 level Likert scale, with 1 being strongly disagree and 5 being strongly agree. The questions are separated into sections, with the first section on demographic and independent variables, second section on financial literacy questions and the last section for another set of independent variables. Once all the respondents filled in the form, this data was exported into Microsoft Excel spreadsheet. Here, the questions are then coded for Statistical Package for Social Sciences (SPSS). Moreover, as the dependent variable compromises of 18 questions, the data was transformed by assigning everyone to their own class of financial literacy; poor, average and good based of the answers each respondent provided.

Once done, the data is transferred to SPSS, and coded. Two of the independent variables which are upbringing and influence comprises of a set of questions, hence they underwent transformation in SPSS. Five tests are employed via SPSS to find the relationship between our variables. The five tests used are the descriptive statistics, normality test, reliability test, correlation test and regression analysis. The test is to determine the significance of our independent variables which are level of education, level of income, marital status, upbringing, and influence 
with the dependent variable. Two of the independent variables which are upbringing and influence comprises of a set of questions, hence they underwent transformation in SPSS.

\section{DATA ANALYSIS AND RESULTS}

In seeking the empirical evidence on the factors determining financial literacy, the theoretical model of the study led to the development of five hypotheses.

Starting with R-square, the value shown is 0.167 , which signifies that the variables adopted in this study which are education level, level of income, marital status, upbringing, and influence explains 16.70 per cent of the dependent variable which is financial literacy. Hence, another 83.30 per cent can be explained by other variables outside of this study as factors for financial literacy of millennials in Malaysia. Moving on to the F-statistics from the ANOVA where it evaluate the significance of the study. Using the 95 per cent confidence level, a significant value under 0.05 indicates that the model is significant and otherwise if value is over 0.05 . The significance is at 0.002 , hence the study is significant at 95 per cent level as significant F-statistics is under 0.05.

The same confidence level is adopted for significance of independent variables and dependent variables in this study at 95 per cent confidence level. From the table, we see that education level is significant with financial literacy of millennials in Malaysia at 0.015. Moreover, level of income is also seen to be significant at 0.026 with financial literacy. Thus, both education level and level of income are significant with financial literacy of millennials at 95 per cent confidence level as both significant values are under 0.05. In contrast, marital status reports a significant value of 0.766 , showing that is not significant with financial literacy. As for upbringing, the significant value is at 0.386 , also signifying its insignificant with financial literacy. Lastly, influence has a significant value of 0.728 with financial literacy. These three variables are not significant with the dependent variable as the significant value has exceeded 0.05 .

Next, Beta represent the coefficient of the direction of the independent variables of the study either positive or negative. Education level shows a coefficient of 0.108 , level of income with 0.115 , marital status with coefficient of 0.043 and influence with a coefficient of 0.020 . These four independent variables show a positive coefficient value, signifying its positive relationship with the dependent variable which is financial literacy of millennials in Malaysia. On the contrary, upbringing exhibits a coefficient of -0.054, hence it has a negative direction. Thus, upbringing has a negative relationship with financial literacy of millennials in Malaysia.

\section{DISCUSSION OF FINDINGS}

Table 1 showed the validity of the hypothesis of this study. Based off the table, only $\mathrm{H} 1$ and $\mathrm{H} 2$ were accepted, while $\mathrm{H} 3, \mathrm{H} 4$ and $\mathrm{H} 5$ were rejected. $\mathrm{H} 1$ was accepted whereby education level has shown a positive and significant relationship with financial literacy rate of millennials in Malaysia. This means that those who are more educated and have a higher education level will have a higher financial literacy rate. This is in line with the research done by Kimiyaghalam and Yap (2017) where their findings find that post graduate individuals exhibit a higher financial literacy than the others.

Table 1. Summary of hypothesis testing.

\begin{tabular}{c|c|c|c|c}
\hline Hypothesis & Causal Relationship & $\mathbf{B}^{\mathbf{1}}$ & $\mathbf{P}^{\mathbf{1}}$ & Result $^{\mathbf{s}}$ \\
\hline H1 & EDUC $\rightarrow$ FINLIT & 0.108 & $0.015^{2}$ & Accept \\
\hline H2 & INCOME $\rightarrow$ FINLIT & 0.115 & $0.026^{2}$ & Accept \\
\hline H3 & MARITAL $\rightarrow$ FINLIT & 0.043 & 0.766 & Reject \\
\hline H4 & UPBRING $\rightarrow$ FINLIT & -0.054 & 0.386 & Reject \\
\hline H5 & EXTINF $\rightarrow$ FINLIT & 0.020 & 0.728 & Reject \\
\hline
\end{tabular}

Note: ${ }^{1}$ Regression Coefficient.

'Statistical Significant of the Test $(\alpha=0.05)$.

${ }^{3}$ Results on Null Hypothesis Test. 
Moreover, $\mathrm{H} 2$ is also accepted whereby there is a positive and significant relationship between level of income and financial literacy rate of millennials in Malaysia. Level of income is positively and significantly correlated with financial literacy; the financial literacy level of an individual depends on their income (Bhushan \& Medury, 2013).

H3 was rejected as there is a positive but insignificant relationship between marital status and financial literacy rate of millennials in Malaysia. From the regression analysis, we see that the coefficient is positive however it was not significant with the dependent variable. This is supported by a study done by Murugiah (2016) and Joo and Grable (2004) where marital status does not have any significant impact towards financial literacy and the relationship of these two variables are denied. However, it is not in line with findings of Marzieh et al. (2013) and Grigion et al. (2015) that implied that those who are married or have more marital responsibilities are more financially literate.

$\mathrm{H} 4$ which posited that there was a positive and significant relationship between upbringing and financial literacy rate of millennials was rejected. Results shows a negative relationship instead and it is not significant with the financial literacy rate of millennials in Malaysia. This contradicts many of the findings of previous researchers such as Norvilitis and MacLean (2010); Pinto et al. (2005) as they stated that parents influence and upbringing towards their children affects the financial literacy and money management of their children. Most of these research papers investigates on population in the United States, hence there might be a cultural difference between Malaysia and USA, hence parental influence and upbringing may not be significant in the financial literacy rate of millennials in Malaysia.

Similarly, H5 was also rejected whereby there was a positive and insignificant relationship with financial literacy rate of millennials in Malaysia. Results shows a positive but not significant relationship; hence, the hypothesis is rejected. The results contradicted the findings of Ismail et al. (2011), also Sabri and Aw (2019) where these researchers had implied that internet and media have an influence towards the increasement of financial literacy. This contradictory result may be due to a standpoint from respondents of this study who did not utilize the internet to aid their financial literacy. However, the results were in line with findings of Sabri and Aw (2019) where they have stated that media have an undesired impact towards financial literacy, hence this was not a significant factor towards financial literacy.

There are many institutions such as AKPK that helps many individuals with increasing financial literacy. Some of their programmes include financial education, financial counselling, and debt management programmes. These programmes have helped many individuals here in Malaysia and help turn their lives for the better. The government has also launched several initiatives to combat low financial literacy level such as National Strategy for Financial Literacy 2019-2023.

Moreover, initiatives can be taken by the government such as implementing financial education to the Malaysians at a younger age. The current school syllabus is slowly implementing financial education to students in Malaysia. Moreover, parents can also help to contribute to increase financial literacy rate of millennials in Malaysia by sharing their knowledge, expertise, and opinions on information like credit management, money management and financial knowledge. First-hand information from parents would help the future generation to be more financially literate. Not just that, the use of internet can also help to boost financial literacy rate of millennials. Having a more interesting platform to spread knowledge on financial issues such as social media will help millennials to increase their financial literacy rate. Many parties can take the advantage and create new initiatives to help boost financial literacy rate of millennials in Malaysia.

\section{CONCLUSION}

This study investigates the factors affecting the financial literacy rate of millennials in Malaysia using education level, level of income, marital status, upbringing, and influence as its determinants. Financial literacy is an element in one's financial wellbeing hence it is generally regarded as an important aspect of life. According to 
our findings, millennials in Malaysia shows an average level of financial literacy which shows that millennials are still not fully financially literate in 2020 .

Results shows that education level and level of income has a positive relationship with financial literacy rate of millennials in Malaysia, supported by previous research done. The variables adopted in this study can explain only 16.70 per cent of financial literacy, hence, there are other factors that affect financial literacy of millennials in Malaysia such as peer influences, religious influences, and other financial influences. The findings in this study both supported and contradict previous studies done by past researchers which may be due to factors like small sample size and cultural differences. Most of the independent variables align positively with the dependent variable except for upbringing.

In line with the research findings, there several recommendations that can be made to further improve the financial literacy rate of millennials in Malaysia. The first recommendation that can help increase financial literacy is with the help of AKPK. To have a better understanding AKPK is an agency that helps with credit counselling and debt management for those who needs it. Therefore, AKPK has programs that help individual with financial stability such as Debt Management Programme (DMP). DMP is a program that help with regaining control of an individual's debts properly as this program provide counselling to create a personalized repayment plan. This program is an effort for them to encourage borrowers to be in control with their financial well-being such as negotiating and communicating with their lender.

On the other hand, AKPK also provides financial education to those who needs it which focuses on the responsibility of spending and managing money. The program also consists of practical financial knowledge that is easy to understand and apply. Also, there is debt management for young adults that is borrowers while in a tertiary education. Furthermore, AKPK provides debt management and financial knowledge for individuals who are entering the workforce as to get financial stability.

Next, the second recommendation comes from the government as this entity has a lot of pulling power and influence thus as a whole it can make a great change towards financial literacy. The government can do programs that can aid the public or millennials with financial literacy such as the National Strategy for Financial Literacy 2019 - 2023. As this can bring a lot of benefits for individuals to understand and learn more about financial literacy.

Another movement that the government could do is that expand the school syllabus as to include financial literacy subjects thus they will understand it at a younger age in their lives. Furthermore, the third recommendation will come from non-other than their own parents. Parents should create an incentivize for their children from a young age to teach them financial literacy such as money management, budgeting and more. Therefore, when they grow up while their parents are sharing their financial knowledge and know how; they will have a better understanding and mastery of this topic and will achieve financial stability in life.

The final recommendation that can be made to increase one's financial literacy is by relating parties could create a new initiative that can aid with this battle to make everyone financially literate. Lastly, is that relating parties can create a podcast form that they get on time to time to talk about financial literacy tips and the knowhow. Also, they can create an internet page such as websites, social media, or any media form as to educate the mass public about financial literacy as it can benefit them in life.

For further research of this study which can improve or have a different take on this topic is more than welcome as there is potential to delve more in-depth into this topic. Therefore, further research can be done on this research study by other researchers is extending this study by using different variables as it can help the study to have another angle investigated it. Furthermore, it is beneficial because the study can have another perspective to the financial literacy. Next, future researchers can study or do more in-depth research on the independent variable such as upbringing and influence. It is because these two variables have a lot of power in financial literacy currently. The reason being these variables can indirectly set an individual financial literacy level in this world. Moving on, future researchers should collect more data sample as more data for this study brings more potential to the results 
and will be more representative. Another recommendation to future researchers is to have a more constructive questionnaire or better an interview with respondents as it can help precisely determine an individual level of financial literacy of millennials in Malaysia. With a more constructive question, the data sample collected would be more accurate and precise.

Funding: This study received no specific financial support.

Competing Interests: The authors declare that they have no competing interests.

Authors' Contributions: All authors contributed equally to the conception and design of the study.

\section{REFERENCES}

Atkinson, A., \& Messy, F.-A. (2012). Measuring financial literacy: Results of the OECD/international network on financial education (INFE) pilot study. OECD Working Papers on Finance, Insurance and Private Pensions, No. 15, OECD Publishing.

Beck, J. J., \& Garris, R. O. (2019). Managing personal finance literacy in the United States: A case study. Education Sciences, 9(2), 1-11.Available at: https://doi.org/10.3390/educsci9020129.

Bhushan, P., \& Medury, Y. (2013). Financial literacy and its determinants. International Journal of Engineering, Business and Enterprise Applications, 4(2), 155-160.

Boon, T. H., Yee, H. S., \& Ting, H. W. (2011). Financial literacy and personal financial planning in Klang Valley, Malaysia. International Journal of Economics and Management, 5(1), 149-168.

Calamato, M. P. (2010). Learning financial literacy in the family. Master's Theses.

Clarke, M. C., Heaton, M. B., Israelsen, C. L., \& Eggett, D. L. (2005). The acquisition of family financial roles and responsibilities. Family and Consumer Sciences Research Journal, 33(4), 321-340.

Diener, E., Sandvik, E., Seidlitz, L., \& Diener, M. (1993). The relationship between income and subjective well-being: Relative or absolute? Social Indicators Research, 28(3), 195-223.

Eisner, S. P. (2005). Managing generation Y. SAM Advanced Management Journal, 70(4), 4-17.

Gale, W. G., \& Levine, R. (2010). Ruth, financial literacy: What works? How could it be more effective? Retrieved from https://ssrn.com/abstract $=1758910$.

Grigion, A. C., Vieira, K. M., \& Kirch, G. (2015). Determinants of financial literacy: Analysis of the influence of socioeconomic and demographic variables. Retrieved from: http://www.scielo.br/scielo.php?pid=S1519$\underline{70772015000300362 \& \text { script }=\text { sci_arttext\&tlng }=\text { en }}$.

Huston, S. J. (2010). Measuring financial literacy. Journal of Consumer Affairs, 44(2), 296-316.

Hwee, J., Lin, L., \& Sellapan, R. (2010). Financial planning and youth: Implications in educating generation Y. The 4E Journal, $10(2), 18-20$.

Ismail, S., Serguieva, A., \& Singh, S. (2011). Integrative model of students' attitude to educational loan repayment: A structural modelling approach. Journal of International Education in Business, 4(2), 125-135.Available at: https://doi.org/10.1108/18363261111189522.

Joo, S.-h., \& Grable, J. E. (2004). An exploratory framework of the determinants of financial satisfaction. Journal of Family and Economic Issues, 25(1), 25-50.Available at: https://doi.org/10.1023/B:JEEI.0000016722.37994.9f.

Jorgensen, B. L. (2007). Financial literacy of college students: Parental and peer influences. Unpublished Master's Thesis, Virginia Polytechnic Institute and State University, Blacksburg, Virginia.

Kimiyaghalam, F., \& Yap, S. (2017). Level of financial literacy in Malaysia. International Journal of Research, 4(7), $1065-1075$.

Lusardi, A., \& Mitchell, O. (2007). Financial literacy and retirement preparedness: Evidence and implications for financial education. Business Economics, 42(1), 35-44.

Lusardi, A., \& Mitchell, O. S. (2011). Financial literacy and retirement planning in the United States. Journal of Pension Economics E Finance, $10(4)$, 509-525. 
Lusardi, A., \& Mitchell, O. S. (2014). The economic importance of financial literacy: Theory and evidence. Journal of Economic Literature, 52(1), 5-44.

Lyons, A. C., Palmer, L., Jayaratne, K. S., \& Scherpf, E. (2006). Are we making the grade? A national overview of financial education and program evaluation. Journal of Consumer Affairs, 4O(2), 208-235.Available at: https://doi.org/10.1111/j.1745-6606.2006.00056.x.

Mandell, L. (2008). Financial literacy of high schools students. Handbook of Consumer Finance Research. New York: Springer.

Marzieh, K. T., Hosein, Z. Z., Mehrizi, S. M. T., \& Roshan, A. (2013). The relation between financial literacy, financial wellbeing and financial concerns. International Journal of Business and Management, 8(11), 63-75.Available at: https://doi.org/10.5539/ijbm.v8n 11 p63.

Mottola, G. R. (2013). In our best interest: Women, financial literacy, and credit card behavior. Numeracy, 6(2), 4.

Murugiah, L. (2016). The level of understanding and strategies to enhance financial literacy among Malaysian. International Journal of Economics and Financial Issues, 6(3), 130-139.

Norvilitis, J. M., \& MacLean, M. G. (2010). The role of parents in college students' financial behaviors and attitudes. Journal of Economic Psychology, 31(1), 55-63.Available at: https://doi.org/10.1016/j.joep.2009.10.003.

Pinto, M. B., Parente, D. H., \& Mansfield, P. M. (2005). Information learned from socialization agents: Its relationship to credit card use. Family and Consumer Sciences Research Journal, 33(4), 357-367.Available at:
https://doi.org/10.1177/1077727x04274113.

Sabri, M. F., \& Aw, E. C.-X. (2019). Financial literacy and related outcomes: The role of financial information sources. International Journal of Business and Society, 20(1), 286-298.

Servon, L. J., \& Kaestner, R. (2008). Consumer financial literacy and the impact of online banking on the financial behavior of lower-income bank customers. Journal of Consumer Affairs, 42(2), 271-305.Available at: https://doi.org/10.1111/j.17456606.2008.00108.x.

Tie, S. C., \& Nizam, I. (2016). Determinants of financial well-being for generation Y in Malaysia. International Journal of Education, Learning and Training, 1(1), 36-52.

Xu, L., \& Zia, B. (2012). Financial Literacy around the World: An overview of the evidence with practical suggestions for the way forward. Policy Research Working Paper; No. 6107. World Bank, Washington, DC. (C) World Bank.

Yew, S., Yong, C., Cheong, K., \& Tey, N. (2017). Does financial education matter? Education literacy among undergraduates in Malaysia. Institutions and Economies, 9(1), 43-60.

Views and opinions expressed in this article are the views and opinions of the author(s), International Journal of Publication and Social Studies shall not be responsible or answerable for any loss, damage or liability etc. caused in relation to/arising out of the use of the content. 